\title{
ПРЕДИКТОРИ ІНТЕНСИВНОГО ПІСЛЯОПЕРАЦІЙНОГО БОЛЮ У ПАЦІЄНТІВ ПІСЛЯ ЛАПАРОСКОПІЧНОЇ ХОЛЕЦИИТЕКТОМІЇ
}

\author{
Ю. Л. Кучин, К. Ю. Бєлка, В. П. Бабич \\ Інститут післядипломної освіти Національного медичного університету імені О. О. Богомольця, м. Київ
}

\section{PREDICTORS OF SEVERE POSTOPERATIVE PAIN IN PATIENTS AFTER LAPAROSCOPIC CHOLECYSTECTOMY}

\author{
Yu. L. Kuchin, K. Yu. Byelka, V. P. Babych \\ Institute of Postgraduate Education of Bogomolets National Medical University, Kyiv
}

\section{Реферат}

Післяопераційний біль (ПОБ) часто $є$ основною скаргою у пацієнтів після лапароскопічної холецистектомії (ЛХЕ), саме його наявність та інтенсивність нерідко визначають тривалість госпіталізації пацієнтів, якість їх життя після операції. Визначення предикторів інтенсивного ПОБ після ЛХЕ допоможе виявляти пацієнтів з високим ризиком його виникнення, вчасно фрормулювати алгоритм їх лікування, покращити його результати, зменшити ризик переходу болю у хронічний. Метою проспективного дослідження було визначення предикторів інтенсивного ПОБ у пацієнтів після ЛХЕ. У дослідження включені 100 пацієнтів, у 20 з них після ЛХЕ виник інтенсивний ПОБ. Предикторами інтенсивного ПОБ були: жіноча стать, молодий вік, наявність інтенсивного болю перед операцією, хронічного болю, передопераційної тривоги та/або депресії. При аналізі даних встановлено, що у пацієнтів, яким інтраопераційно призначали кетамін, частота інтенсивного ПОБ менша.

Ключові слова: лапароскопічна холецистектомія; післяопераційний біль; предиктори.

\section{Abstract}

Postoperative pain (POP) is often a main complaint in patients after laparoscopic cholecystectomy (LCHE). Its presence and intensity often determine the duration of hospitalization and postoperative quality of life. Identification of the predictors of severe POP after LCHE will allow to reveal the patients at high risk, to form the treatment algorithm, to improve the treatment results, to decrease the risk of transformation into chronic pain. The purpose of the prospective study was to determine of intensive POP predictors in patients after LCHE. 100 patients were included to investigation, in 20 of them after LCHE the severe POP was appeared. The predictors of severe POP were female gender, young age, severe pain before the surgery, chronic pain, preoperative anxiety and/or depression. Patients who received ketamine during the surgery had lower rate of severe POP.

Keywords: laparoscopic cholecystectomy; postoperative pain; predictors.

Біль є багатофакторним суб'єктивним відчуттям, що спричиняє у пацієнта стрес, розлади дихання, гемодинаміки, імунної відповіді, коагуляції [1]. ЛХЕ загалом характеризується значно меншою інтенсивністю ПОБ, ніж відкрита холецистектомія [1]. Проте, часто біль є основною скаргою у пацієнтів після лХЕ, у більшості (80\%) з них потрібне використання опіатів з метою знеболення [2]. Використання опіатних аналгетиків та власне ПОБ зумовлюють збільшення тривалості госпіталізаціï 26 - 41\% пацієнтів, виникнення ускладнень та побічних реакцій, значне погіршення якості життя пацієнтів після виписування [1]. Крім того, інтенсивний ПОБ може бути предиктором появи хронічного болю [3].

Механізм ПОБ після ЛХЕ є мультифакторним, включає декілька компонентів: соматичний біль - виникає в місці встановлення троакарів (у 50 - 70\%) хворих; вісцеральний біль - внаслідок інтраабдомінальної травми в зоні оперативного втручання (у 10 - 20\%); вісцеральний біль - через значне натяжіння очеревини, тракцію судин і нервів, подразнення діафрагмального нерва, вивільнення прозапальних цитокінів (у 20 - 30\%) [2]. За даними літератури, абдомінальний ПОБ виникає у 70 -96\% пацієнтів після ЛХЕ, біль в правому плечі - у 10\% [4, 5]. ПОБ після ЛХЕ варіює за інтенсивністю, тривалістю, характером, як правило, його інтенсивність максимальна протягом 6 - 12 год після операції, зменшується через 2-3 доби. Біль в плечі триває у середньому 24 год [4]. Інтенсивність ПОБ у більшості хворих помірна - за візуально-аналоговою шкалою (ВАШ) у середньому від 20 до 60 мм, у 10 - 20\% - більше 70 мм [6].

Відомими предикторами інтенсивного та помірного ПОБ після ЛХЕ
$€$ жіноча стать, інтенсивний передопераційний біль, блювання, нудота, відчуття тиску в животі [7] перед операцією; психологічні фактори - передопераційні тривога, депресія; толерантність до болю; молодий вік [8]. Більшість досліджень предикторів інтенсивного ПОБ після ЛХЕ описові або ретроспективні, з невеликою виборкою пацієнтів та низьким рівнем доказовості.

В Україні відсутні дані статистики ПОБ після ЛХЕ та дослідження предикторів помірного або інтенсивного ПОБ.

Визначення предикторів інтенсивного ПОБ після ЛХЕ допоможе виявляти пацієнтів 3 високим ризиком його виникнення та вчасно формулювати алгоритм їх лікування, покращити його результати, зменшити ризик появи хронічного болю.

Метою дослідження було визначення предикторів інтенсивного ПОБ у пацієнтів після ЛХЕ. 


\section{МАТЕРІАЛИ I МЕТОДИ ДОСЛІДЖЕННЯ}

Проспективне обсерваційне дослідження проведене на клінічній базі кафедри хірургіi, анестезіології та інтенсивної терапії у Київській міській клінічній лікарні № 1 у 2016 р. Протокол дослідження затверджений комісією з етики Національного медичного університету імені О. О. Богомольця. У дослідження включені 100 пацієнтів, яким планували та виконали ЛХЕ.

Критеріями включення у дослідження були: вік від 18 до 75 років, підписана пацієнтом або його законним представником поінформована згода на участь у дослідженні.

Не включали у дослідження пацієнтів віком до 18 і старше 75 років, за неможливості отримати поінформовану згоду.

У пацієнтів оцінювали інтенсивність болю з використанням ВАШ у спокою та під час рухів перед та через кожні 1 - 2 год протягом 48 год після операціі. Критерієм інтенсивного ПОБ вважали 70 мм або більше у спокою (за ВАШ) протягом щонайменше 30\% часу після операції. Відповідно, залежно від інтенсивності ПОБ пацієнти розподілені на 2 групи: у 20 (20\%) пацієнтів (група 1) - відзначений інтенсивний ПОБ; у 80 (80\%) пацієнтів (група 2) - ПОБ легкий або помірної інтенсивності.

Для аналізу предикторів інтенсивного ПОБ виділені групи факторів ризику: 1) демографічні дані (вік, стать, рівень освіти); 2) інтенсивний передопераційний біль; 3) блювання або нудота перед операцією; 4) наявність хронічного болю до операції (не пов'язаного з основним захворюванням); 5) наявність перед операцією психічних розладів - тривожності, депресії; 6) наявність супутніх захворювань, анестезіологічний ризик

Статистичний аналіз включав використання логістичної регресії для виявлення статистично значущих предикторів інтенсивного ПОБ та порівняння значень (критерій Манна-Уітні) або частоти факторів (подвійний критерій Фішера). Категоріальні дані представлені як пропорції, неперервні - як медіана та 25 - 75 квартилі. Для визначення нормальності розподілу даних у виборці використовували тест $\chi^{2}$, біль-

Результати дослідження предикторів інтенсивного ПОБ після XE

\begin{tabular}{|c|c|c|c|c|}
\hline \multirow[b]{2}{*}{ Предиктор } & \multicolumn{4}{|c|}{ Величина показника в групі } \\
\hline & $\begin{array}{c}1 \\
(n=20)\end{array}$ & $\begin{array}{c}2 \\
(n=80)\end{array}$ & $\begin{array}{c}\text { ВШ } \\
\text { (95\% ДІ) }\end{array}$ & $\mathrm{p}$ \\
\hline Жінок/чоловіків & $14 / 6$ & $35 / 45$ & $\begin{array}{c}3 \\
(0,95-10,43)\end{array}$ & 0,046 \\
\hline \multicolumn{5}{|l|}{ Вік, років } \\
\hline $18-30$ & 2 & 1 & $\begin{array}{c}146 \\
(3-869)\end{array}$ & 0,003 \\
\hline $30-65$ & 1 & 73 & - & 1 \\
\hline $65-75$ & - & 23 & - & 1 \\
\hline $\begin{array}{l}\text { Інтенсивний } \\
\text { передопераційний біль }\end{array}$ & 17 & 10 & $\begin{array}{c}40 \\
(10-155)\end{array}$ & 0,0001 \\
\hline Хронічний біль & 6 & 4 & $\begin{array}{c}9 \\
(1,6-43)\end{array}$ & 0,004 \\
\hline $\begin{array}{l}\text { Передопераційна } \\
\text { тривога/депресія }\end{array}$ & 12 & 8 & $\begin{array}{c}13,5 \\
(4-50) \\
\end{array}$ & 0,0001 \\
\hline $\begin{array}{l}\text { Високий анестезіологічний } \\
\text { ризик (ASA III) }\end{array}$ & 5 & 15 & $\begin{array}{c}1,44 \\
(0,4-4)\end{array}$ & 0,54 \\
\hline Ожиріння & 8 & 32 & - & 1 \\
\hline Рівень освіти, вища & 10 & 36 & - & 0,8 \\
\hline $\begin{array}{l}\text { Інтраопераційне використання } \\
\text { кетаміну }\end{array}$ & 1 & 21 & $\begin{array}{c}6,8 \\
(1,1-14)\end{array}$ & 0,03 \\
\hline \multicolumn{5}{|l|}{ Супутні захворювання } \\
\hline ХОЗЛ & 1 & 5 & - & 1 \\
\hline цүкровий діабет & 2 & 9 & - & 1 \\
\hline хронічні хвороби нирок & 1 & 4 & - & 1 \\
\hline артеріальна гіпертензія & 6 & 23 & - & 1 \\
\hline
\end{tabular}

шість результатів у дослідженні є непараметричними. Вірогідність вважали значущою при $\mathrm{p}<0,05$.

\section{РЕЗУЛЬТАТИ}

Пацієнти у досліджуваних групах не різнились за віком: у групі 1 - вік хворих від 42 до 61 року, медіана 46 років; у групі 2 - від 40 до 58 років, медіана 45 років. Групи зіставні також за частотою виявлення супутніх захворювань: хронічних хвороб нирок ( $\mathrm{p}=1)$, артеріальної гіпертензіi $(\mathrm{p}=1)$, хронічних обструктивних захворювань легень - ХОЗЛ ( $\mathrm{p}=1)$, цукрового діабету ( $\mathrm{p}=1)$; а також ступенем анестезіологічного ризику $(\mathrm{p}=0,54)$, наявністю ожиріння ( $=1$ ) та рівнем професійної освіти ( $=0,8)$.

Предикторами інтенсивного ПОБ були: жіноча стать (відношення шансів - ВШ 3, 95\% довірчий інтервал - ДІ 0,95 - 10,43); молодий вік (ВШ 146, 95\% ДІ 3-869); наявність інтенсивного передопераційного болю (ВШ 40, 95\% ДІ 10-155); хронічного болю (ВШ 9, 95\% ДІ 1,6-43); передопераційної тривоги та/або депресії (ВШ 13,5, 95\% ДІ 4-50). У пацієнтів, яким інтраопераційно призначали кетамін, частота інтенсивного ПОБ була менша (ВШ 6,8, 95\% ДІ 1,1-14). У таблиці представлений аналіз частоти предикторів інтенсивного ПОБ після ЛХЕ

\section{ОБГОВОРЕННЯ}

ПОБ після ЛХЕ $є$ досить частим ускладненням, від 35 до 65\% пацієнтів відчувають помірний або інтенсивний біль у перші 48 год [6], він асоціюється з гіршими результатами лікування - збільшенням тривалості госпіталізації, частоти післяопераційних ускладнень [6]. Покращення післяопераційного знеболення на підставі аналізу предикторів інтенсивного ПОБ та мінімізації використання опіатів допоможе більш швидкому одужанню пацієнтів, зменшенню частоти ускладнень.

У теперішній час опубліковані поодинокі дослідження з вивчення предикторів інтенсивного ПОБ [6, 9], 3окрема, один систематичний огляд 48 досліджень за участі 23037 пацієнтів. За даними авторів, вік найчастіше мав негативну кореляцію з застосуванням аналгетиків та інтенсивністю болю [6], що також показане у нашому дослідженні: у пацієнтів мо- 
лодого віку вищий ризик інтенсивного ПОБ, ніж у пацієнтів похилого віку. Щодо гендерних розбіжностей, дані неоднозначні, деякі дослідники виявили такий зв'язок, інші - не підтвердили його $[6,9]$. В нашому дослідженні жіночий вік був достовірним предиктором інтенсивного ПОБ. Не вивчений вплив маси тіла, рівня освіти, анестезіологічного ризику [6], в нашому дослідженні ці чинники не асоціювалися 3 збільшенням ризику ПОБ. Тривожність та інші психіч-

\section{ЛITEPATУPA/REFERENCES}

1. Sarakatsianou SR, Georgopoulou S, Tzovaras G. Acute pain management in laparoscopic cholecystectomy: Is there a role for pregabalin? A review. The Greek E-Journal of Perioperative Medicine. 2016;14:15-24.

2. Mitra S, Khandelwal P, Roberts $\mathrm{K}$, et al. Pain relief in cholecystectomy - A review of the current options. Pain Practice. 2012;12(6):485-96.

3. Bisgaard T. Analgesic treatment after laparoscopic cholecystectomy: A critical assessment of the evidence. Anesthesiology. 2006;104:835-46.

4. Dabbagh A. Pain after Laparoscopic cholecystectomy. Zanco J Med Sci. 2009;13:23-8.

5. Joris J, Thiry E, Paris P. Pain after laparoscopic cholecystectomy: characteristics and effect of intraperitoneal bupivacaine. Anesth Analg. 2005;81:379-84.
6. Jabbour-Khoury S. Intraperitoneal and intravenous routes for pain relief in laparoscopic cholecystectomy. SLS. 2005;9:316-21.

7. Ure BM, Troidl H, Spangenberger W, et al. Pain after laparoscopic cholecystectomy. Intensity and localization of pain and analysis of predictors in preoperative symptoms and intraoperative events. Surg Endosc. 1994;8(2):90-6.

8. Hui Y, Abrishami A, Philip W, et al. Predictors of postoperative pain and analgesic consumption: A qualitative systematic review. Anesthesiology. 2012;117(4):755-64.

9. Aouad MT, Kanazi GE, Malek K, et al. Predictors of postoperative pain and analgesic requirements following abdominal hysterectomy: an observational study. J Anesth. 2016;30(1):72 - 9. 